\title{
JACQUES MARITAIN
}

For many of us Jacques Maritain embodied what hope remains for this dark world. His death in Toulouse on April 28, 1973, at the age of ninety, has left us bereft, as if he had been both our godfather and our godson.

His important place in the history of human thought was established long before most of us knew him personally. For example, I was nineteen, in my first year at Princeton, when I first met him, and he was sixty-seven, recently retired from the French Embassy to the Holy See. We became close friends and remained so for twenty-four years.

His association with this review was long and affectionate as was his association with the University of Notre Dame, which takes pride in its Jacques Maritain Center. But apart from these personal associations is the recognition due to his works of the mind and spirit.

As long as reason was regarded as an adequate tool for knowing (and for knowing, among other things, other ways of knowing), the Western world generally preferred some form of the mind-matter dualism. Semitic religions, when they came to take up these modes of expression, discovered that they could subscribe to no other basic philosophy. Profiting from the chemistry of their own heresies, as well as by the discomfort which Islam had experienced in attempting to bring Aristotelian dualism into harmony with Koranic dualism, mediaeval Christianity sought a summation of theology in which no part of reality would be overlooked. Precisely such a summation is believed by many, including myself, to have been supplied by St. Thomas Aquinas in the thirteenth century. But just as the theological content of this particular summation, the systematized expression of one infinitely rich, indeed inexhaustible, Divine Revelation, was meant to germinate further speculation, so was its philosophical content. I know of no mind that examined the philosophical content of the Thomistic synthesis with greater precision, interpreted it with greater probity, advanced its growth with greater genius, than the mind of Jacques Maritain.

There is a timelessness about his work simply because it bears the imprint of the whole history of thought. To attack or defend it seriously is to attack or defend any of many categories: the classical 
province of philosophy itself; its tool, reason; the basic philosophical position called dualism; the statement of that position by Aquinas; its translation and extension (or some parts of it) by Maritain. As it happens, none of these categories has stood immune of attack in our times.

What Maritain did about it, however, was to bear constant witness to the truth as he knew it. He said and wrote often enough that it was not his business, nor that of any human being, to secure the triumph of truth, but only to be its witness. I myself do not profess to know what there is in men that makes them desire such living witnesses to truth; but they do desire them, fervently and insatiably, for all the realms truth touches, from common sense to mystical theology. And Maritain was a witness in no fewer realms: as a philosopher he witnessed to the corpus of truth (to which he himself added) attainable by unaided human reason; as a Catholic Christian, he witnessed to the corpus of truth which is given only through faith and grace, which surpasses and enlivens the participating truths.

I regard Maritain's testimony as a philosopher to constitute the more amazing and urgent aspect of his life of witnessing. The Church is divinely assured, after all, that she will never lack witnesses; poor philosophy enjoys no such assurance. Moreover, in an intellectual climate like the one in which Jacques Maritain's world operated, and in which so large a part of our world operates, that very functioning of reason which is capable of preparing the human mind for receiving suprarational truth has been perversely inverted nearly to suicide. It was a great and laudable thing for Pope Leo XIII, the Dominican Order, and Louvain University to have lifted Thomism out of the bookstacks; but it was an even greater and more laudable thing, in my opinion, for Maritain to have divebombed it into the very center of the world's intellectual and cultural crisis. As an example I recall an evening when I was among a small group including Albert Einstein, Julian Huxley and J. Robert Oppenheimer, and heard the sole basis of agreement among the group specifically defined as Maritain's address before the Second International Conference of UNESCO at Mexico City in 1947.

In his brilliant preface to The Angelic Doctor, Maritain set forth the claims of Thomism to the philosophical peerage. "There is a Thomist philosophy," he wrote; "there is no neo-Thomist philosophy. We make no claim to include anything of the past in the 
present, but to maintain in the present the 'actuality' of the eternal ... Thomism claims to make use of reason to distinguish truth from falsehood; it does not want to destroy but to purify modern speculation and to integrate all the truth that has been discovered since the time of St. Thomas. It is an essentially synthetic and assimilative philosophy, the only philosophy which, as a matter of fact, attempts throughout the ages and the continents a work of continuity and universality ... I assert that truth does not pass, does not flow away with history; that the spirit does not disintegrate, that there are stabilities not of inertia but of spirituality and life; intemporal values; eternal acquisitions; that time is in the eternal like a gold piece in the clutch of the hand; and that the mind is above time."

I once saw a note in the handwriting of Pope Pius XII thanking Maritain for bringing his speculative philosophy into the French Embassy to the Holy See. I think similar thanks are due his memory for having brought it to the shores of the United States of America. Of course they loved him in Chicago, South Bend, New Haven, Princeton, and throughout the country. But he also, let it never be forgotten, loved this country, less for the hospitality it gave him and Raissa and Véra during desperate times than for the reserves for philosophy and contemplation which he discemed within it and burned to enlist for the intellectual and spiritual causes in which he believed so fervently.

An outrageous friend of mine once put it quite nicely when he said that someday a truly American altar will possess two reliquaries, one containing a piece of charred wood that burned the Jesuit Martyrs, the other a piece of chalk used by Jacques Maritain in teaching philosophy at Princeton.

-James Kritzeck 